\title{
PLC Kontrollü Kurutucu Konveyör Tasarımı
}

\author{
Orçun KÜÇÜKATAY*1, Ercan KÖSE ${ }^{2}$, Zehra YILDIZ ${ }^{3}$ \\ ${ }^{1}$ Tarsus Üniversitesi, Lisansüstü Eğitim Enstitüsü, İmalat Mühendisliği Bölümü, Mersin \\ ${ }^{2}$ Tarsus Üniversitesi, Mühendislik Fakültesi, Elektrik Elektronik Mühendisliği Bölümü, Mersin \\ ${ }^{3}$ Tarsus Üniversitesi, Mühendislik Fakültesi, Makine Mühendisliği Bölümü, Mersin
}

Geliş tarihi: 05.03.2021 Kabul tarihi: 31.03.2021

\begin{abstract}
Öz
Güneşle kurutma yönteminin dezavantajların ortadan kaldırılması için endüstriyel ortamda kurutma sistemleri geliştirilmiştir. PLC kontrollü kurutucu konve yör tasarımında, hiçbir elektriksel kaynak kullanılmadan tamamen çevreci bir şekilde gıdaların doğal güneş 1şı̆̆ını kullanarak kurutulması amaçlanmış ve sistem tasarlanmıştır. PLC kontrollü kurutucu konveyör sistemi, şeffaf bir materyalle üzeri kapatılmış dikdörtgen prizma şeklinde bir kurutma kabininden oluşmaktadır. Sisteme nem ve sıcaklık sensörleri ile ağırlık ölçer eklenmiş ve sistemin PLC ile kontrolü sağlanmıştır. Sistemde 1 saniyelik periyotlarda sıcaklık, nem ve kurutulan maddedeki ağırlık değişimleri algılanarak PLC hafızasına kaydedilmektedir. Tüm kurutma parametreleri algılayıcılar vasitasıyla izlenip kaydedilerek cihazın kurutma performansı ve çevresel faktörlerdeki değişim, PLC hafızasında depolanan sayısal datalar vasitasıyla PLC üzerinden grafiksel olarak izlenebilmektedir.
\end{abstract}

Anahtar Kelimeler: PLC, G1da, Kurutma, Sistem tasarımı

\section{PLC Controlled Dryer Conveyor Design}

\begin{abstract}
Drying systems have been developed for industrial applications in order to eliminate the disadvantages of the sun drying method. In the PLC controlled dryer conveyor design, it is aimed to dry foods using natural sunlight in a completely environmentally friendly way without using any electrical sources. Dryer conveyor system with PLC controlled consists of a rectangular prism shaped drying cabinet covered with a transparent material. Humidity and temperature sensors and a weight meter were added to the system and thus the system was controlled by PLC. In the system, temperature, humidity and weight changes in the dried material are detected and recorded in the PLC memory in 1 second periods. All drying parameters are monitored and recorded by sensors and saved in PLC memory. Drying performance of the device and the change in environmental factors can be graphically monitored via PLC with the help of recorded numerical data.
\end{abstract}

Keywords: PLC, Food, Drying, System design

*Sorumlu yazar (Corresponding author): Orçun KÜÇÜKATAY, okucukatay@gmail.com 


\section{GíRiș}

Ürün kalitesinde bozulma olmadan meyvelerin, sebzelerin ve yiyeceklerin uzun süre saklanması çok önemlidir. Gıda ürünlerini korumak için endüstriyel ölçekte bazı proses teknolojileri kullanılmaktadır. $\mathrm{Bu}$ proseslerden en yaygın ve ekonomik olanı kurutma tekniğidir. Bu tekniğin tercih edilmesinde en önemli kıstas; kurutma masrafları, kurutma süresi ve kurutulmuş ürünlere verilen zararı azaltabilecek enerji kullanımı ve üretilen gıda maddelerinin kalitesidir [1]. Kurutma işlemi, gıdadan suyun uzaklaştırılarak uzun süreli depolama için gıdanın uygun şartlara getirilmesi işlemidir. Kurutma ile gıda ürünlerinin dayanıklılığının arttırılması sağlanır. Ayrıca kurutma işlemi sonucunda gıdalar, içeriğindeki nem miktarı düştüğünden depolama işlemi için gereken hacimsel büyüklük de azalmaktadır.

$\mathrm{Bu}$ çalışmada, mevsimsel koşullardan dolayı erik meyvesi mevsiminde kurutulmuş ve değerler tespit edilmiştir. Sistemde güneş 1şınlarının kapalı mekanizma içerisindeki gıda ürünlerine direkt olarak ulaşması ürünlerin daha kısa süre içerisinde neminin alınmasına olanak sağlamıştır. Kapalı kabin içerisi sıcaklığı, dış mekân sıcaklığının 10$15{ }^{\circ} \mathrm{C}$ üzerinde olduğu gözlemlenmiştir. Ayrıca Kurutma ünitesine gıda ürünlerinin ilk yerleşimi ve kurutma işlemi sonrası tahliyesi için konveyör sistemi yerleştirilmiştir. Konveyör sistemi sayesinde kurutulan ürünlerin daha kısa süre içerisinde tahliye edilmesine olanak sağlanması hedeflenmiştir. Bu çalışmada kurutucu konveyör sistemi (KKS) tasarımı ve imalatı gerçekleştirilmiştir. KKS, doğrudan (pasif) güneş enerjili kabin tipi kurutma sistemidir. Eksenel fan yerleştirilmiş sistemde, kurutma kabininin üzeri cam kaplı yalıtımlı olarak tasarlanmış ve imal edilmiştir. Kabin içine hız kontrollü taşıyıcı konveyör bant yerleştirilmiştir. Konveyör bant vasıtasıyla otomatik olarak belli bir hızda ilerleme sağlanabilmekte ve ürünün yüklenmesi ve boşaltılması yapılabilmektedir. Bir kütle ölçer sayesinde ürünün ilk kütlesi, kurutma işlemi esnasında belli aralıklarla kütle takibinin yapılmasına izin vermektedir. Ayrıca kütle ölçümü, kurutma işlemleri için çok önemli olan takip işleminin gerçekleştirmesini de sağlamıştır.

\section{2. ÖNCEKİ ÇALIŞMALAR}

Bayhan (2004), $40{ }^{\circ} C^{\prime}$ 'den $70{ }^{\circ} C^{\prime}$ 'ye değişen sicaklikta $0,8-1,5 \mathrm{~m} / \mathrm{s}$ hava hizlarinda izgara altından yapılan üflemeli ve $60{ }^{\circ} \mathrm{C}$ sıcaklıkta aynı hava hızında 1zgara üstünden üflemeli olmak üzere iki farklı kabin tipi kurutucuda eşit miktardaki aynı cins nane numunelerini kurutma işlemine tabi tutarak kurutma sürecini etkileyen parametreleri karşılatırmış ve grafiksel olarak incelemiştir [2]. Along ve Hammed (2007) kolektörün eğim açıs1 konuma ve mevsime göre değişebilecek doğrudan pasif bir güneş kurutucuyu mevcut yerel malzemeler kullanılarak tasarlamışlar ve test etmiştir. \%62'lik (1slak bazda) başlangıç nem içeriğinde 2,16 kg kütlesinde iplik yongası, yatayla $260^{\circ}$ 'lik bir açı yapacak şekilde yerleştirilen güneş kurutucusunda kurutularak, nem içeriği \%11,11'e (1slak bazda) düşürülmüştür [3]. Akdeniz (2011), sultani çekirdeksiz üzüm çeşidi için geleneksel yöntemlerle güneşte kurutma işlemi hakkında bilgiler vermiştir [4].

Yıldız ve Gökayaz (2019) çok raflı güneş enerjili kurutucu ile elma kurutmuşlar ve kurutma süresi, dilim kalınlığ 1 ve tepsiye yüklenen dilimlerin kütlesi gibi kurutma parametrelerini Yanıt Yüzey Yöntemi ile optimize etmişlerdir. En fazla nem kaybı ve büzülme oranı minimum kuruma hızı için kurutma süresi 159-274 dakika, tepsiye yüklenen elma dilimlerinin kütlesi 92,86-105,72 g ve elma dilim kalınlığ $6,48-6,667$ mm olarak bulmuşlardır [5].

Gürel ve arkadaşları (2016), kurutma öncesi işlemlerin ürünlerin hazırlanmasını, önişlemleri, nem içeriklerinin belirlenmesi aşamalarını kapsadığını; kurutma sonrası analizlerin ise, ürünün renk, doku, büzülme, gözeneklilik, tat, su aktivitesi, rehidrasyon, raf ömrü, besin değerleri vb. değerlendirmeleri kapsadığını belirterek gıda kurutulması işlemleri sırasında uygulanan kurutma prosedürlerini incelemişlerdir [6]. Güngör (2013), kurutucu içinde sürekli bir iletim bandında hareket ettirilen gida maddesine sıcak kurutma havası üflenerek kurutulmasını sağlamıştır [7]. 


\section{MATERYAL VE METOT}

Şekil 1'de Kurutma Sistemine ait perspektif resim verilmiştir. Sistem; kurutma kabini, şeffaf malzeme, konveyör ve bant, endüstriyel kontrol malzemeleri ve sensörler, tartım platformundan oluşur.

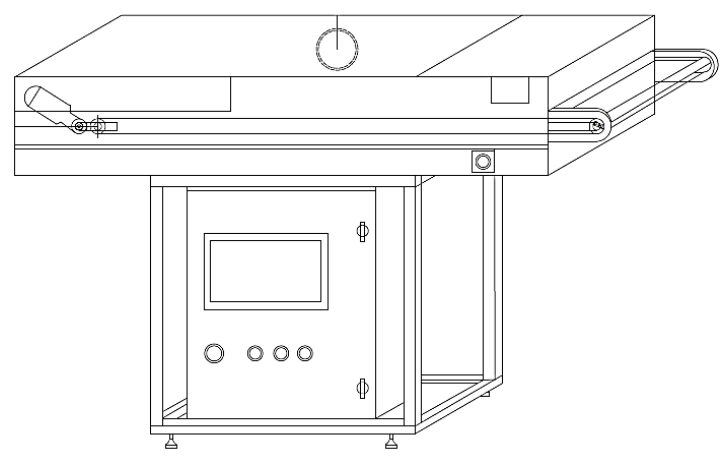

Şekil 1. Kurutma sisteminin perspektif resmi

Kurutma sistemi tasarımının en önemli parçası olan kurutma kabini, $2 \mathrm{~mm}$ sac levhalar kullanılarak imal edilmiştir. Üst tarafı kurutulacak gıdaların direkt güneş 1şığına maruz kalması için şeffaf malzeme ile kaplanmıştır. Kurutma kabini ölçüleri $141 \mathrm{~cm}$ uzunluk, $55 \mathrm{~cm}$ genişlik, $15 \mathrm{~cm}$ yükselti olacak şekilde tasarlanmıştır. Kurutma ünitesi tabanına konveyör bant yerleştirilmiştir. Konveyör bant, gıdaları yerleştirmek ve kurutmakta sonunda da tahliye işlemini gerçekleştirmektedir. Ayrıca kurutma kabini içerisindeki sıcaklık ve nem değerlerinin algılanması için iki adet sıcaklık algılayıcı ve 1 adet nem algılayıcı kullanılmıştır.

Şekil 2'de kurutma kabininin üstten görünüşü verilmiştir. Resim üzerindeki A ve B: kabin içi sıcaklık algılayıcıları, C: kabin içi nem algılayıcısı, D: hava deliği E: emiş fanını temsil etmektedir.

Konveyör sistemi ve otomasyon üniteleri platform üzerine montajlanmıştır. Sistem üzerinde konveyör sisteminin yönüne göre sol taraftan meyveler yerleştirip sağ taraftan ise kurutulmuş meyveler tahliye edilecektir. Kurutma sisteminin ana kaidesinin imalatı için metal sac ve profiller kullanılmıştır.

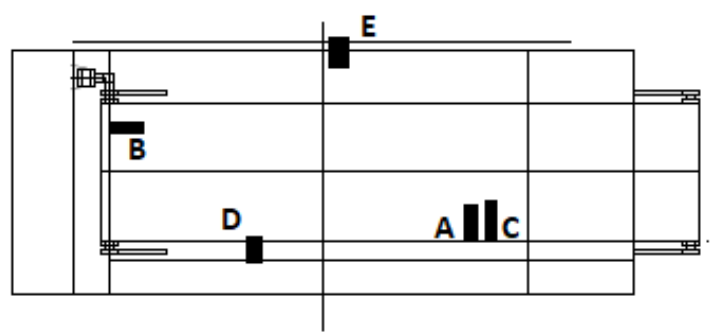

Şekil 2. Kurutma kabininin üstten görünüşü

Şekil 3'te Tartım platformu ve ağırlık ölçerin montaj edilmiş görünümü verilmiştir. Şekilde görüldüğü gibi ana kaidenin altında bulunan tartım ünitesin merkezine bir adet ağırlık ölçer (loadcell ünitesi) yerleştirilmiştir. Kurutma süresi boyunca kurutulan numunelerin ağırlık verileri saniyelik olarak kaydetmektedir. Özel olarak tasarlanan bu tartım platformu $50 \mathrm{~cm} \quad$ x $60 \mathrm{~cm} \quad$ x $12 \mathrm{~cm}$ ölçülerindedir.

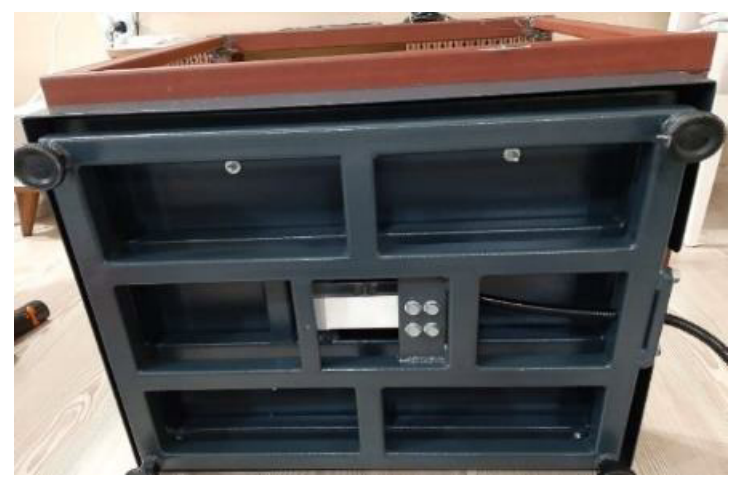

Şekil 3. Tartım platformu ve ağırlık ölçerin montaj edilmiş görünümü

Şekil 4'te göründüğü gibi kurutma sisteminin arka kısmında ortam havasının nemini ölçen nemölçer ve emiş fanı bulunmaktadır. Kurutma ünitesindeki nem saniyelik olarak ölçülmekte ve PLC hafızasına kaydedilmiştir. Ayrıca PLC kontrollü kurutucu konveyör kurutma sisteminin imalatının yapılmış hali Şekil 5'te gösterilmiştir. Görüldüğü gibi kurutma işleminin kontrolü ve sayısal takibini yapmak için bir izleme ekranı sistem kaidesinin gövdesine monte edilmiştir.

Sistem içi sıcaklıları ölçmek için, iç sıcaklık algılayıcılar kabin içine, dış ortam sıcaklığını ölçmek için dış sıcaklık algılayıcılar kabin üzerine 
yerleştirilmiştir. Kabin içi nemi algılamak için nem sensörü kabin içine yerleştirilmiştir. Kabin altına ağırlık ölçerler kullanılarak kurutma süresince kurutulan maddedeki ağırlık değişimleri algılanmıştır. Saniyelik olarak algılanan datalar PLC hafızasında kayıt altına alınmaktadır. Böylece kurutma işlemi boyunca iç ve diş sıcaklık ve nem değişimleri, kurutulan maddedeki ağırlık değerleri izlenerek kayıt altına alınabilmektedir. Ayrıca hafızadaki sayısal değerlerin değişimleri ve sistemin kurutma performansı zamana ve çevresel faktörlere göre değişimi grafiksel olarak izlenebilme imkânı vermektedir.

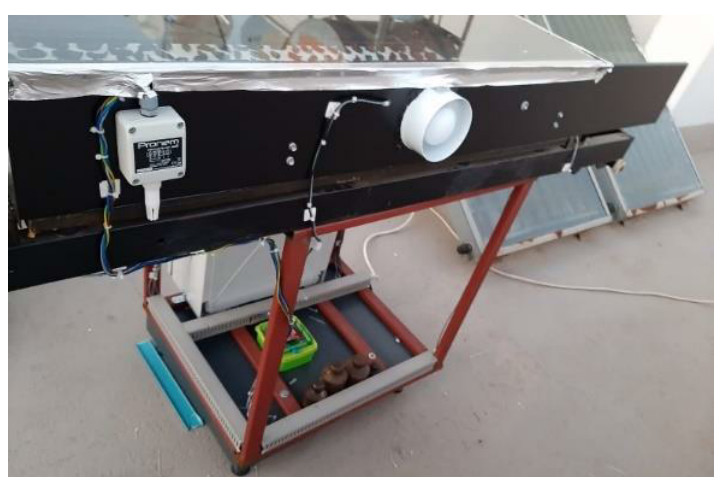

Şekil 4. Kurutma sisteminde nemölçer ve emiş fan1 görünüşü

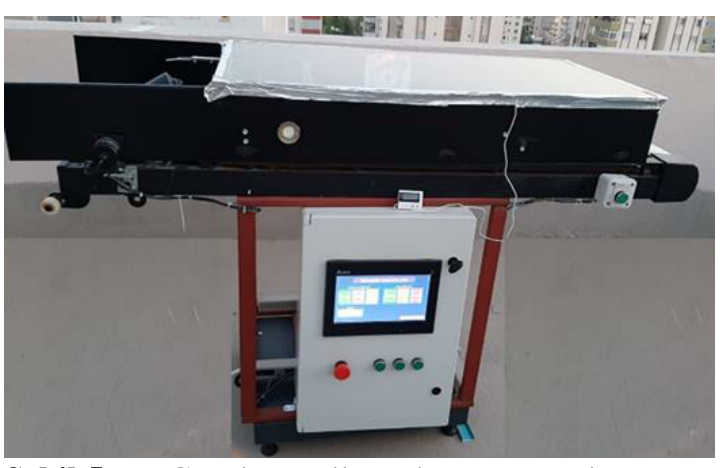

Şekil 5. PLC kontrollü kurutucu konveyör tasarımı

PLC kontrollü kurutucu konveyör sistemi kurutma deneyleri deniz seviyesinden $110 \mathrm{~m}$ yükseklikte, etrafı $0,9 \quad \mathrm{~m} \quad \mathrm{~d}$ ış bir çatı üzerinde gerçekleştirilmiştir. Hava akımının rahat bir şekilde gerçekleşmesi için cihaz dış duvardan
0,7 m uzaklıkta bir noktaya konumlandırılmıştır. Cihazın geniş olan cephesi güneşten radyasyonla olan 1sı transferini en üst seviyeye çıkartabilmek için güney yönüne doğru konumlandırılmıştır.

Şekil 6' da PLC operatör panelinde sensör ekranı gösterilmiştir. Sistemin kontrolü için kullanılan ve ekran görüntüsü verilen sensörlerden elde edilerek oluşturulan sayısal değerleri takip etmek için "Sensör Değerleri” sayfası bulunmaktadır. Bu sayfa aracılığıyla ölçülen anlık değerlerin sürekli olarak izlenmesi sağlanmıştır. Gözlemlenen veriler aynı zamanda sistem hafizasına kaydedilmektedir.

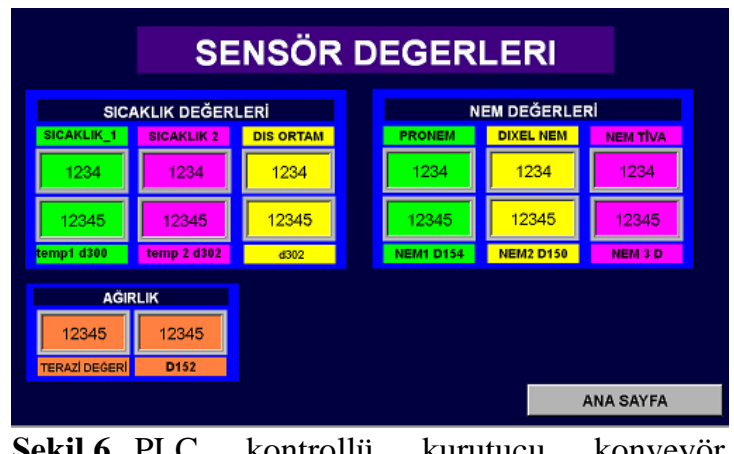

Şekil 6. PLC kontrollü kurutucu konveyör tasarımı

Operatör paneli üzerinde sicaklık_1 ve sicaklık_2 algılayıcıları kurutma ünitesi iç sıcaklığını ölçmek için kullanılmıştır. Ayrıca dış ortam sıcaklık algılayıcısı ile diş ortam sıcaklığı ölçülmüştür. Sistemde iki adet bağıl nemölçer kullanılmıştır. Bunlardan biri dış ortam, diğeri ise kabin içi bağıl nem değerini ölçmektedir. Kurutma işlemlerinin gerçekleştirildiği süre içerisinde eksenel fan sürekli çalıştırılmaktadır.

Yapılacak testin veri kayıtlarının tutabilmek için bir ara yüz yazılımı kullanılmıştır. Ara yüz yazılımı Şekil 6'da görünen test sayfası aracılığı ile sistemin ayarlanması ve kurutma işleminin izlenmesi için kullanılmıştır. Ekran üzerinde bulunan konveyör adım sayısı ekranında ise konveyör bant üzerinde bulunan encoderin adım sayısını belirlemek için kullanılır. Konveyör üzerindeki encoder meyvelerin yüklenmesi ya da kurutulan ürünlerin tahliyesinde konveyörün ileri 
yönde hareket değerinin istenilen değerde hassas olarak ayarlanması amacı ile kullanılmaktadır. Şekil 7'de kurutma sisteminin izlenmesi ve kontrol edilmesi için test ekranı verilmiştir.

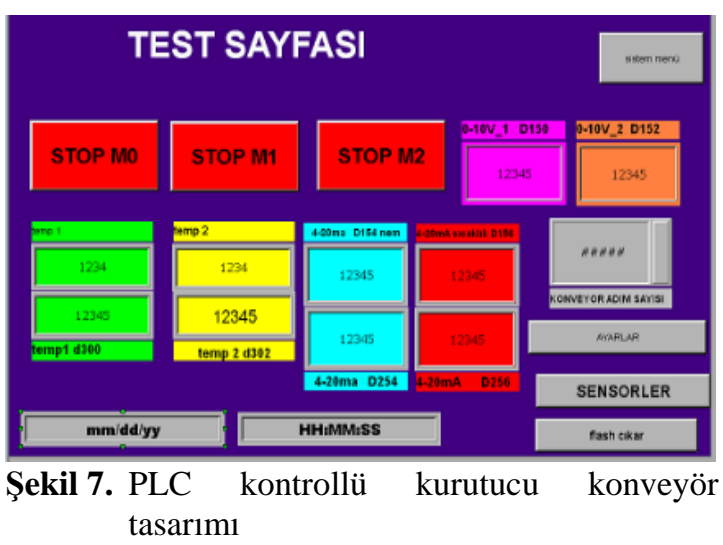

Su içeriği ve gerekse su aktivasyonu bakımından çok yüksek değerlere sahip erik meyvesinin kurutulması için hasat işleminin yapıldığı ilk günler olan Eylül ayında kurutma yapılmıştır. Kurutma işlemine başlamadan önce kabin içine yarım erik materyalleri Şekil 8'de görüldüğü gibi konveyör bant üzerine yerleştirilmiştir. Birbirine temas etmeksizin yerleştirilmiş erik materyali güneşin olduğu saatlerde kurutma işlemine tabi tutulmuştur.

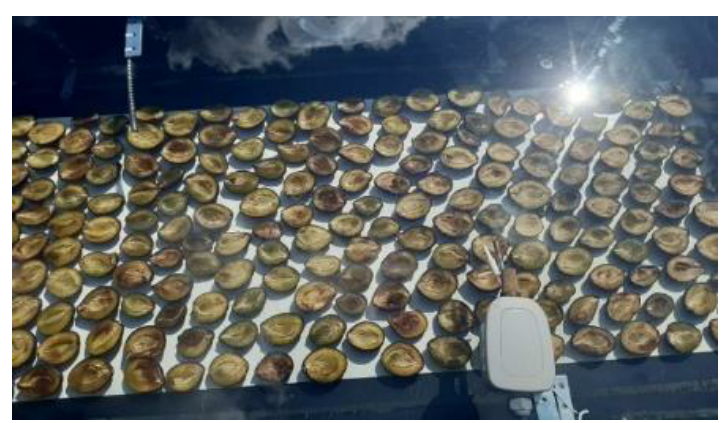

Şekil 8. Kurulacak olan erik numunelerinin kabin içinde yerleşimi

Kurutma işlemi güneşin yoğun olduğu saatlerde yapılmıştır. Deneyler günlük ortalama 8 saat olmak üzere 7 gün sürmüştür. Erik numunelerinin kurutma işlemi sonundaki görünümü Şekil 9'da gösterilmiştir.

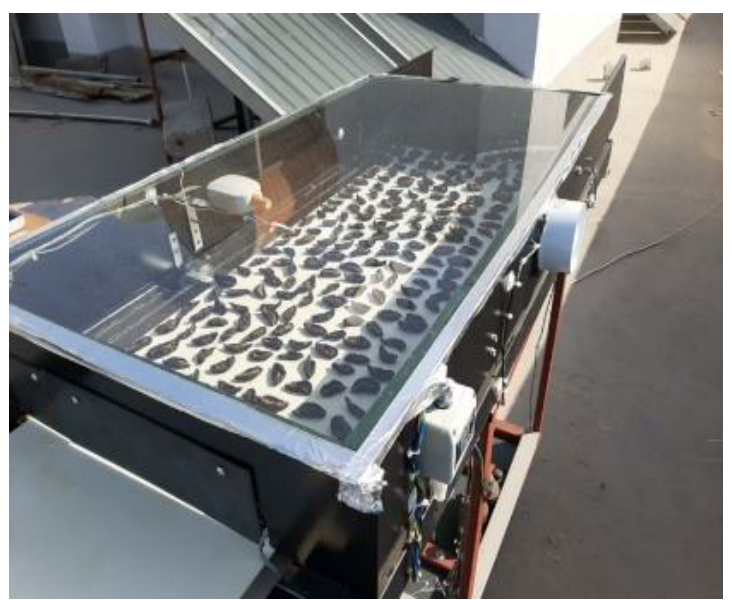

Şekil 9. Numunelerin kurutma işlemi sonundaki görünümü

\section{SISTEM TASARIMINDA KULLANILAN ALGILAYICILAR VE EKİPMANLAR}

\subsection{Ağırlık Ölçer}

Ağırlık ölçer olarak loadcell kullanılmıştır. Loadcell'in teknik özellikleri Çizelge 1'de listelenmiştir.

\subsection{Kullanılan Algılayıcılar}

Kurutma sisteminin sicaklıklarının kabin içi ve dış1 sıcaklık ölçümü için 3 adet sicaklık algılayıcı sisteme yerleştirilmiştir. Algılayıcı olarak Şekil 10'da gösterilen bayonet j tipi termokupl seçilmiştir. Çizelge 2'de sıcaklık algılayıcılarının teknik özellikleri verilmiştir.

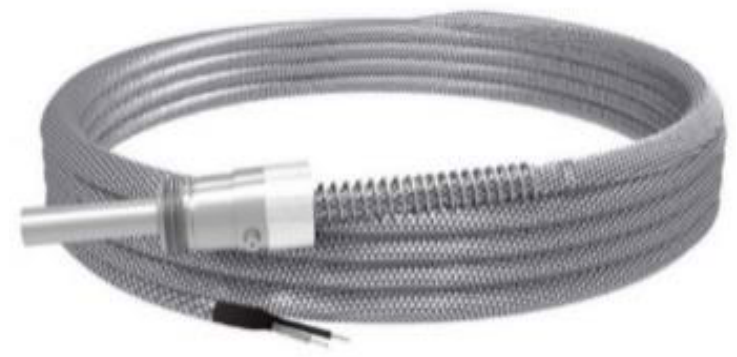

Şekil 10. Sıcaklık algılayıcısı [9] 
Çizelge 1. Ağrılık ölçerin (loadcell) teknik özellikleri [8]

\begin{tabular}{|c|c|}
\hline Özellik & Açıklama \\
\hline Kapasite: & $50 \mathrm{~kg}$ \\
\hline Doğruluk sınıfı: & C3 \\
\hline Minimum yük: & $0 \mathrm{~kg}$ \\
\hline Maksimum bölüntü sayısı: & 3000 \\
\hline Minimum ölçüm aralığı: & 10000 \\
\hline Toplam hata: & $0,02 \% \mathrm{FS}$ \\
\hline Çıkış kazancı: & $2,00 \pm 0,01 \mathrm{mV} / \mathrm{V}$ \\
\hline Sifir balans1: & $\pm 1 \% \mathrm{FS}$ \\
\hline Giriş direnci: & $400 \Omega \pm 20 \Omega$ \\
\hline Çıkış direnci: & $352 \Omega \pm 3 \Omega$ \\
\hline İzolasyon direnci: & $\begin{array}{l}\leq 5000 \mathrm{M} \Omega \\
(100 \mathrm{VDC})\end{array}$ \\
\hline Çalışma sıcaklık aralığı: & $-30^{\sim}+70^{\circ} \mathrm{C}$ \\
\hline $\begin{array}{l}\text { Tavsiye edilen uyarma } \\
\text { gerilimi: }\end{array}$ & $10 \mathrm{VDC}$ \\
\hline $\begin{array}{l}\text { Maksimum uyarma gerilimi } \\
\left(\mathrm{u}_{\max }\right) \text { : }\end{array}$ & $15 \mathrm{VDC}$ \\
\hline Aşırı yükleme kapasitesi: & $120 \% \mathrm{FS}$ \\
\hline Kırılma yükü: & $200 \% \mathrm{FS}$ \\
\hline Koruma sinıfi: & IP 65 \\
\hline Yük hücresi malzemesi: & Alüminyum \\
\hline Kablo: & $4 \times 0,22 \mathrm{~mm}^{2}$ \\
\hline
\end{tabular}

Çizelge 2. Sıcaklık algılayıcıların teknik özellikleri

\begin{tabular}{|l|l|}
\multicolumn{2}{l}{$[9]$} \\
\hline $\begin{array}{l}\text { Özellik } \\
\text { Maksimum çalışma } \\
\text { sıcaklığı: }\end{array}$ & $\begin{array}{l}\text { Çelik örgü kablo için } \\
400^{\circ} \mathrm{C}\end{array}$ \\
\hline Standart kablo türleri: & $\begin{array}{l}\text { Cam elyaf + cam elyaf + } \\
\text { çelik örgü, 2x 0,22 mm }\end{array}$ \\
\hline Sensor tipi: & $\begin{array}{l}\text { DIN/IEC-584 “J” FeCu- } \\
\text { Ni E= J, }\end{array}$ \\
\hline $\begin{array}{l}\text { Koruyucu kılıf } \\
\text { malzemesi: }\end{array}$ & Nikel kaplı pirinç \\
\hline Konektörü: & $1 / 4$ x 19” \\
\hline
\end{tabular}

\subsection{Nem Ölçerler}

Sistem üzerinde monteli nem algılayıcılarından bir tanesi dış ortam, diğeri ise kabin içerisindeki kurutulacak gidaların bulunduğu ortamın bağıl nem değerini analog sinyallere dönüştürüp PLC üzerinde sayısal değerler elde etmek için kullanılmıştır. Elektriksel çıkış olarak 0-10V ya da
4-20 mA çıkış verebilmektedirler. Şekil 9'da nem ölçerin cihaz üzerindeki görünümü verilmiştir. Şekil 11a'da Pronem nemölçer verilmiştir. Çizelge 3'te kullanılan nemölçerlerin teknik özellikleri verilmiştir.

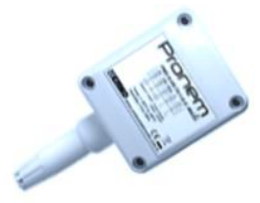

(a)

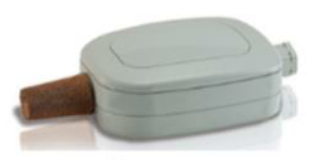

(b)
Şekil 11. (a) Pronem nem ölçer [10] (b) Dixel nem ölçer [11]

Çizelge 3. Pronem nem ölçerin teknik bilgileri [10]

\begin{tabular}{|c|c|}
\hline Özellik & Açıklama \\
\hline Ölçüm aralığı (rh): & $0 \ldots 100 \% \mathrm{RH}$ \\
\hline Ölçüm aralığı (t): & $-20 \ldots+80^{\circ} \mathrm{C}$ \\
\hline Doğruluk (RH): & $\begin{array}{l}+/-2 \% \mathrm{RH} \text { (Typ) at } 23 \\
{ }^{\circ} \mathrm{C}\end{array}$ \\
\hline Doğruluk (T): & $\begin{array}{l}+/-0,3{ }^{\circ} \mathrm{C}(\mathrm{Typ}) \text { at } 23 \\
{ }^{\circ} \mathrm{C}\end{array}$ \\
\hline Kararlilik (RH): & $<0,5 \%$ RH/y1l (Typ) \\
\hline Kararlılık (T): & $<0,04{ }^{\circ} \mathrm{C} / \mathrm{y} 1 \mathrm{l}$ (Typ) \\
\hline $\begin{array}{l}\text { Analog çıkış sinyali } \\
\text { doğruluğu (gerilim): }\end{array}$ & $+/-\% 0,1$ \\
\hline $\begin{array}{l}\text { Analog çıkış sinyali } \\
\text { doğruluğu (akım): }\end{array}$ & $+/-\% 0,5$ \\
\hline Çalışma sıcaklığı aralığı: & $-40^{\circ} \mathrm{C} \ldots+85^{\circ} \mathrm{C}$ \\
\hline
\end{tabular}

Şekil 11(b)'deki nemölçer, bulunduğu ortamdaki bağıl nem değerini 0-10V ya da 4-20 mA analog sinyallere dönüştürmektedir. Güç kaynağ1 olarak 9-18V DC veya $15-35 \mathrm{~V} \mathrm{DC/} 12-24 \mathrm{~V}$ AC kullanılabilir. Doğruluk değeri $\pm \% 3$, çalışma sicaklığı aralığg; 0-70 ${ }^{\circ} \mathrm{C}\left(32-158{ }^{\circ} \mathrm{F}\right)$ 'dir. Bağıl nem ölçümü \%0-99 aralığındadır [11].

\subsection{Operatör Paneli}

PLC kontrollü kurutucu konveyör sistemi üzerinde kullanılan dokunmatik operatör paneli, ekran üzerinden sistemin izlenmesi, konveyör bandın çalıştırılması, sıcaklık, nem değerleri ve kütle 
bilgilerinin belirli periyodlar ile kayıt altına alınması için kullanılmaktadır. Operatör paneli sayesinde sistem üzerinde bulunan tüm algılayıcı değerleri, ekran üzerinden anlık olarak izlenebilmektedir. Çizelge 4'te dokunmatik panelin teknik özellikleri listelenmiştir.

Çizelge 4. Dokunmatik panelin teknik özellikleri

\begin{tabular}{|l|l|}
\multicolumn{1}{c}{$[12]$} \\
\hline Özellik & Aç1klama \\
\hline Ebat: & $\begin{array}{l}10,1^{\prime \prime}(1024 \text { x } 600 \text { piksel) TFT LCD } \\
65536 \text { renk }\end{array}$ \\
\hline $\begin{array}{l}\text { Bağlantı } \\
\text { noktası: }\end{array}$ & $\begin{array}{l}\text { 3 set COM bağlantı noktas1, destek } \\
\text { RS232 / RS422 / RS485 }\end{array}$ \\
\hline Koruma: & $\begin{array}{l}\text { Dokunmatik ekran IP65 ile } \\
\text { uyumludur }\end{array}$ \\
\hline $\begin{array}{l}\text { Besleme } \\
\text { gerilimi: }\end{array}$ & 24 V DC \\
\hline $\begin{array}{l}\text { Kullanım } \\
\text { yönü: }\end{array}$ & Yatay / dikey ekranı destekler \\
\hline
\end{tabular}

\subsection{PLC Cihazı}

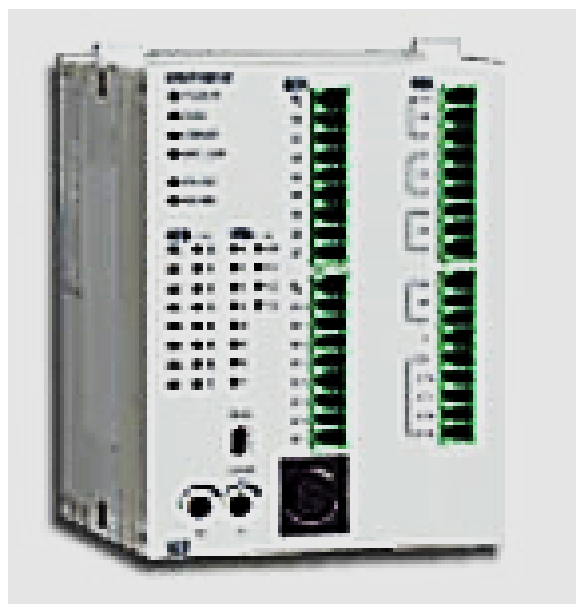

Şekil 12. PLC cihazı [13]

Sistemin kontrolü için kullanılan 16 giriş 12 çıkışlı PLC cihazı Şekil 12'de gösterilmiştir. PLC cihazı kurutma cihazı üzerinde bulunan konveyör bandın hareketini sağlamak, cihaza bağlanan algılayıcıların değerlerinin elektriksel olarak işlenmesi ve operatör bandına verilerin aktarılması amacıyla kullanılmıştır. Sistemde kullanılan PLC cihazının teknik özellikleri Çizelge 5'te listelenmiştir.
Çizelge 5. PLC cihazının teknik özellikleri [13]

\begin{tabular}{|l|l|}
\hline Özellik & Açıklama \\
\hline $\begin{array}{l}\text { Çalışma kontrol } \\
\text { metodu: }\end{array}$ & $\begin{array}{l}\text { Saklı program, saykıl } \\
\text { tarama sistemi }\end{array}$ \\
\hline Giriş Sayısı: & 16 \\
\hline Çıkış Sayısı: & 12 \\
\hline Program Kapasitesi: & 15872 Step \\
\hline Besleme Voltaj1: & 24 VDC \\
\hline Tımer: & 256 \\
\hline Sayıc1: & 16 bit 256 \\
\hline
\end{tabular}

\subsection{Analog Giriş Modülü}

PLC cihazları sıcaklık ve nemölçerlerden gelen elektriksel sinyalleri direkt olarak işleyemezler. Algılayıcıların değerlerinin elektriksel olarak işlenmesi için PLC cihazlarının analog sinyal işleyicilerine ihtiyacı vardır. Bunun için Şekil 13'te gösterilen 4 kanallı analog giriş modülü kullanılmıştır [14]. Analog giriş modülleri girişlerine bağlanan $0-10 \mathrm{~V}$ ya da $4-20 \mathrm{~mA}$ çıkışlı algılayıcıların PLC ile iletişimini sağlayarak PLC cihazının algılayıcılarından gelen bilgileri okumasını sağlarlar.

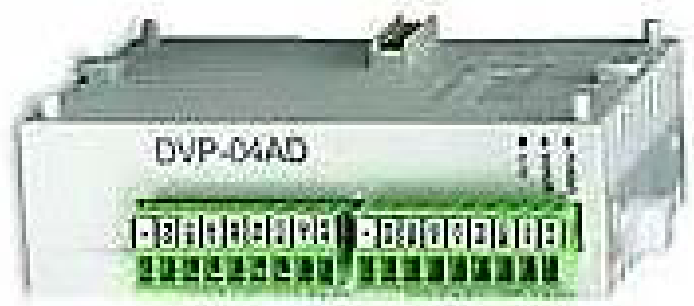

Şekil 13. Analog giriş modülü [14]

\subsection{Tartım İndikatörü}

Şekil 14'te verilen tartım indikatörü, PLC cihazı ile tartım platformu arasındaki elektriksel ilişkiyi sağlamaktadır. Tartım platformları üzerinde bulunan loadcell cihazlarının ürettikleri sinyaller direkt olarak PLC cihazına bağlanamazlar. PLC cihazları ile tartım platformları arasındaki elektriksel uyumu sağlamak için tartım indikatörleri kullanılmıştır. Tartım indikatörü platformdan gelen sinyalleri işleyerek PLC'ye göndermektedir. Çizelge 6'da tartım indikatörünün teknik özellikleri listelenmiştir. 


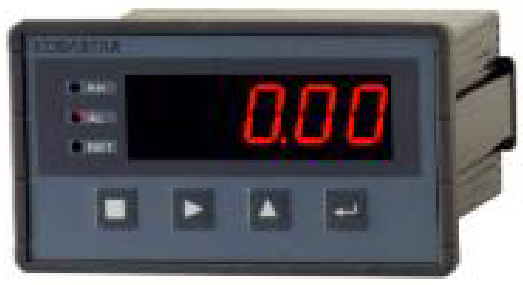

Şekil 14. Tartım indikatörü [15]

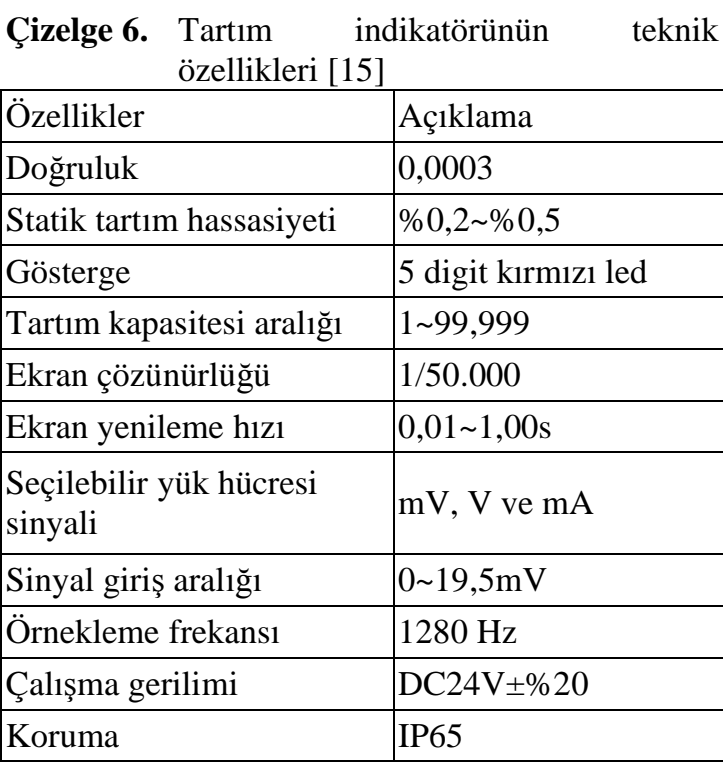

\subsection{PID Kontrol Cihazı}

Şekil 15'te sıcaklık kontrol cihazı olarak kullanılan kontrol ünitesi görülmektedir. Çizelge 7'de kontrol ünitesinin teknik özellikleri listelenmiştir. Kontrol ünitesinin besleme gerilimi 24VDC şeklinde olup sıcaklık algılama için $\mathrm{J}$ tipi termokupl kullanılmıştır.

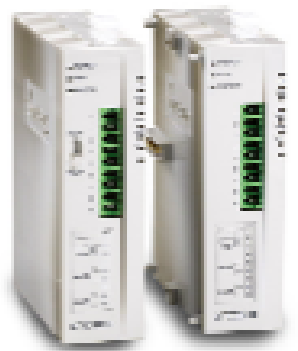

Şekil 15. Kontrol cihaz1 [16]
Çizelge 7. Kontrol cihazının teknik özellikleri [16]

\begin{tabular}{|l|l|}
\hline Özellikler & Açıklama \\
\hline Sensor girişi: & $\begin{array}{l}\text { Termokupl/PT100/0 5 V/ } \\
0 \sim 10 \mathrm{~V} / 0 \sim 20 \mathrm{~mA} / 4 \sim 20 \mathrm{~mA} / \\
0 \sim 50 \mathrm{mV}\end{array}$ \\
\hline Kontrol çıkış1: & $\begin{array}{l}\text { Röle+Röle/4 20 mA/0 10 V/ } \\
\text { SSR (Voltaj Pulse) }\end{array}$ \\
\hline Kontrol tipi: & $\begin{array}{l}\text { ON-OFF/PID/Manuel/PID } \\
\text { Program Kontrol }\end{array}$ \\
\hline Haberleşme: & $\begin{array}{l}\text { Dahili RS485 Modbus } \\
\text { ASCII/RTU }\end{array}$ \\
\hline
\end{tabular}

\section{BULGULAR VE TARTIŞMA}

Sebze ve meyve kurutma amaçlı taşıyıcı konveyör bantlı kabin tipi direkt pasif güneş enerjili kurutma sistemi prototip olarak tasarlanarak, imalat1 yapılmıştır. Tasarlanan sistemin kabin üstüne güneş uygulamalarına uygun cam kaplanmıştır. Hava sirkülasyonu için $100 \mathrm{~m}^{3} / \mathrm{h}$ kapasiteli eksenel fan eklenmiş ve emiş menfezi açılmıştır.

Kurutulacak numuneler ilk önce yıkanmış, tasnif edilmiş ve ikiye bölünerek çekirdekleri çıkarılmıştır. Çekirdekleri çıkarılan numuneler kuruma kabin içerisindeki konveyör bant üzerine düzgün aralıklarla yerleştirilmiş̧ir. Deneysel çalışmalar, havanın durumuna göre günün ilk 1şıklarının etkin olduğu saatlerinde başlatılmış ve gün sonunda sonlandırılmıştır.

Kurutma süresi en az 3 veya dört gün süreceği öngörülmüş olmakla birlikte havanın durumuna (güneşli, bulutlu, yağmur gibi) göre kurutma performansı değişiklik göstermiştir. Kurutulmuş eriğin, yemeye hazır gıda olarak tüketilmesi öngörüldüğü için $\quad \mathrm{MC}_{\mathrm{wb}}=\% 45$ olarak yeterli görülmüştür. İstenilen değerin altında kurutma için güneş radyasyonunun Eylül ayı sonlarına doğru yeterli olmamasından dolayı, daha düşük $\mathrm{MC}_{\mathrm{wb}}$ değerine ulaşılması pratikte de mümkün olmadığı görülmüştür. Uzun süreli ve yüksek sicaklıkta kurutma erik için önerilmediğinden daha uzun kurutma deneyi uygun görülmemiştir. 
Her gün yapilan kurutma deneyi esnasında elde edilen veriler ile çizilen grafiklerden de anlaşılacağı üzere güneş radyasyonu, ortam ve kabin sıcaklığı arasında anlamlı bir ilişki vardır (Şekil 16). Güneş radyasyonu etkisiyle ortam sıcaklığ1 ve kabin içi sıcaklığı değişmektedir.
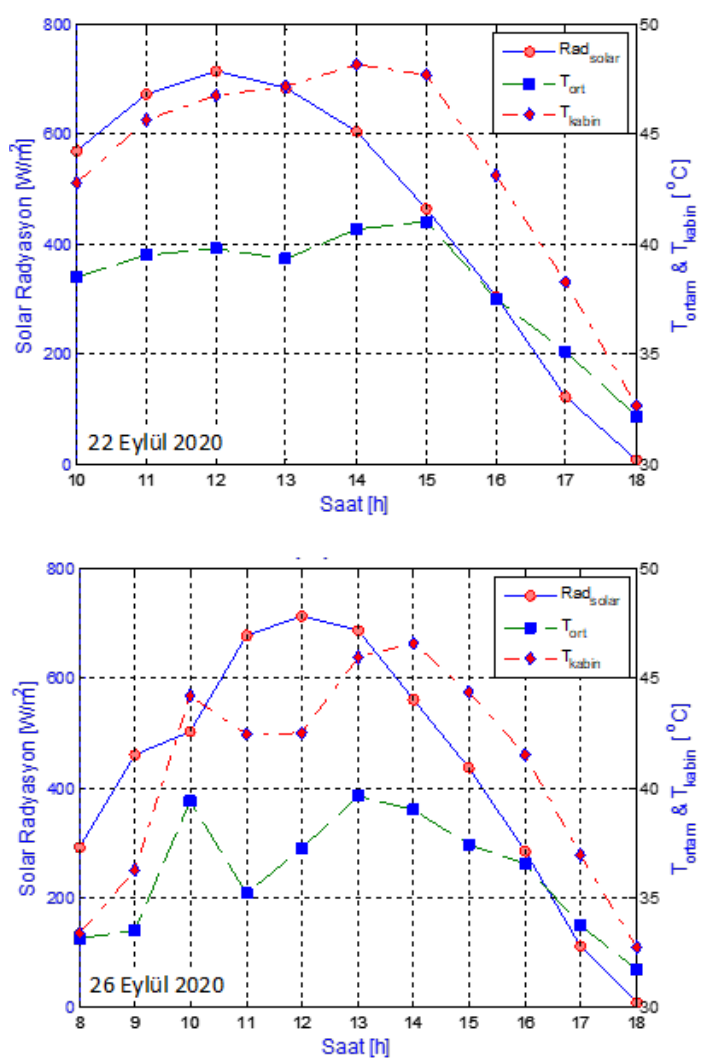

Şekil 16. 22 ve 20 Eylül günlerine ait güneş radyasyonu, ortam ve kabin sicaklık değerleri

Şekil 17'de yeryüzünün güneşlenme oranı ile güneş radyasyonu arasındaki bağıntıyı görmek mümkündür. Her gün için ayrı ayrı çizilmiş grafiklerde bulutlanmanın artmasıyla yatay yüzeye gelen radyasyon oranının azaldığı anlamlı olarak görülmektedir.

Şekil 18'de dört boyutlu olarak bilinen radyasyonun şiddetini gösteren renkli dairesel çizim ve renkli dolgulu çizimlerde, kabin giriş, çıkış, zaman ve radyasyon arasındaki bağıntılar her gün için gösterilmektedir. Güneş radyasyonu arttıkça, kabin giriş ve çıkış sıcaklığının artmasından da anlaşılacağı üzere kurutma sistemi, enerjiyi soğurma konusunda iyi tasarlanmış ve imalatı yeterli seviyede yapılmıştır.
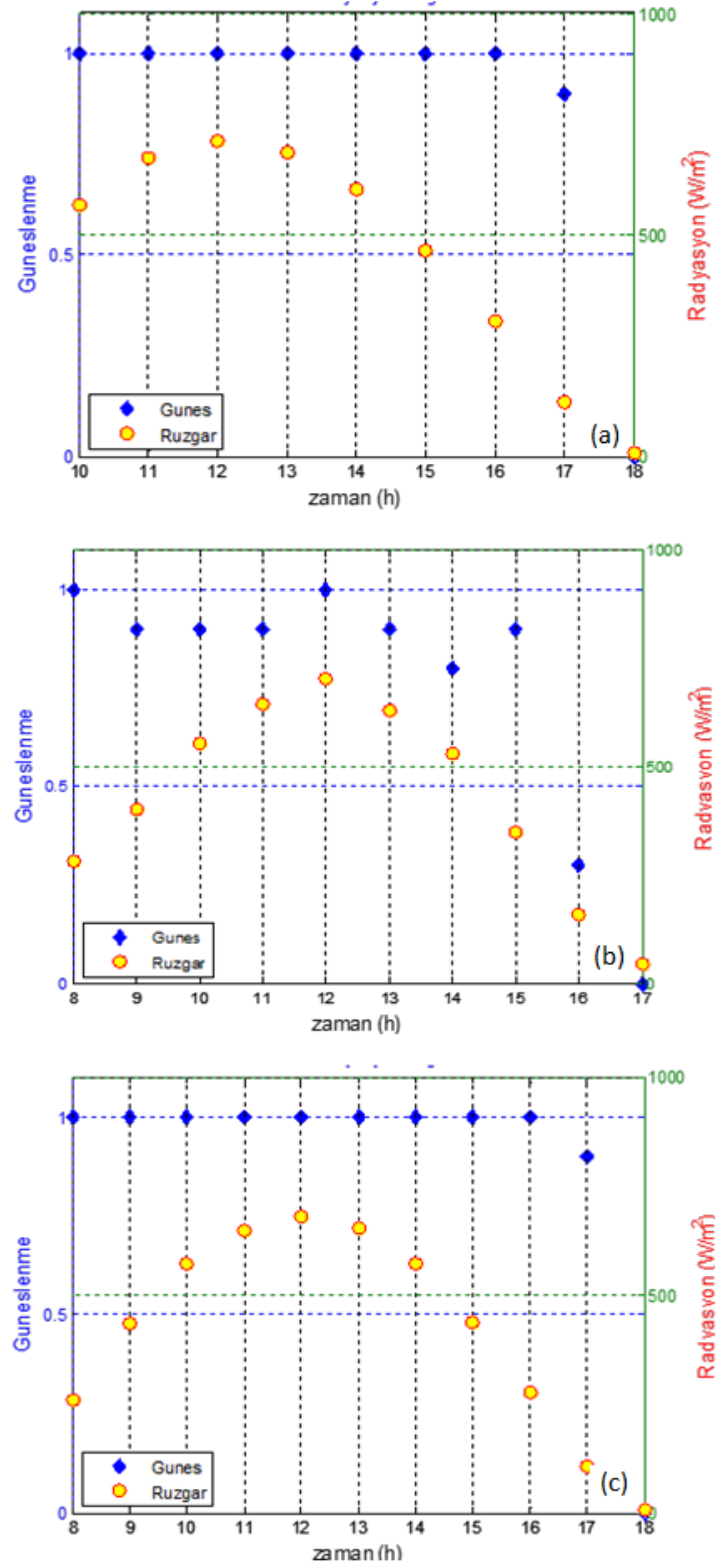

Şekil 17. Kurutma işleminin (a) 1, (b) 4. ve (c) 7. günlerinde, bulutlanma ile güneş radyasyonu arasındaki etkileşim 

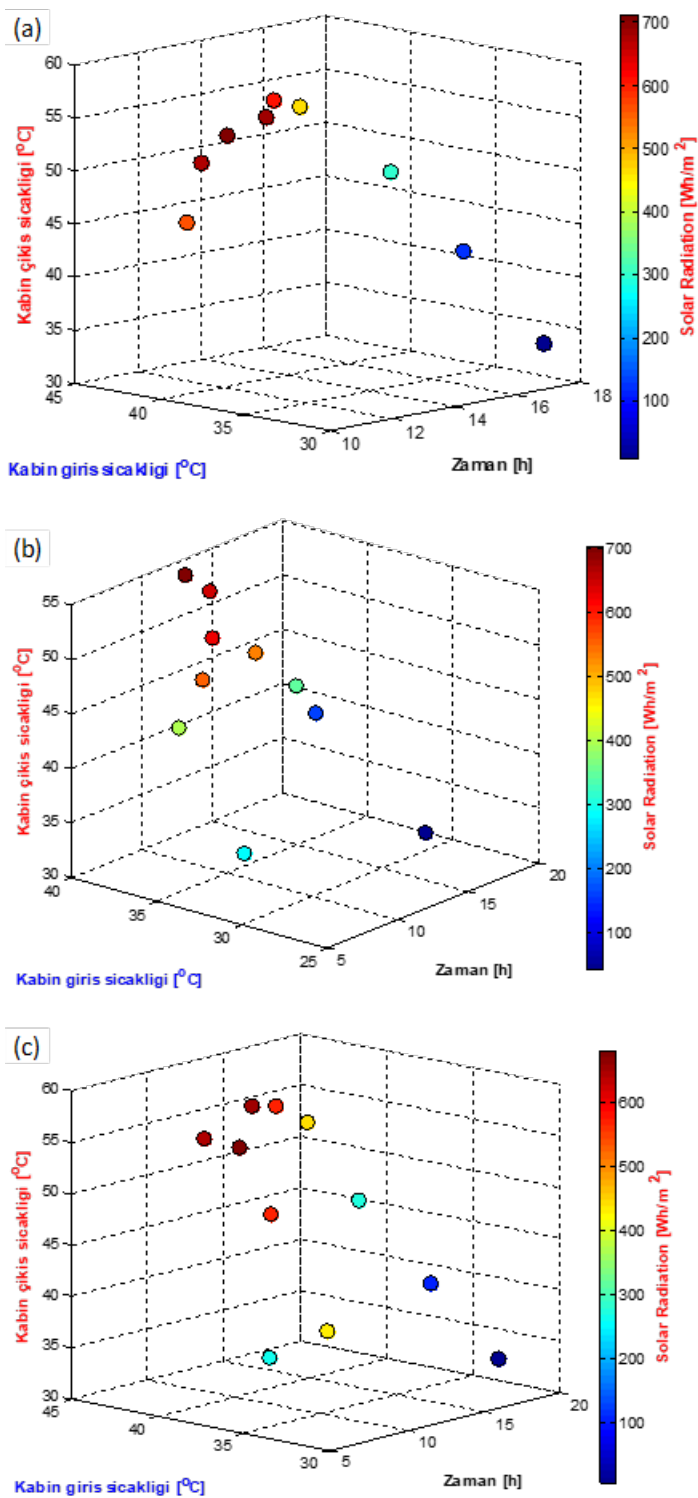

Şekil 18. Kurutma işleminin (a) 1., (b) 4. ve (c) 7 . günlerinde, kabin giriş, çıkış, zaman ve radyasyon arasındaki bağıntılar

Kurutma sisteminin performansını değerlendirme ölçütlerinden biri olan kurutma oranları (MR) her gün için ayrı ayrı hesaplanmıştır. Kurutma için bir günlük sürenin yeterli olmamasından dolayı, sadece güneş enerjisinden faydalanılacağı için aralıklı (kesikli) kurutma yapmak bir zorunluluktur. Ayrı ayrı grafiklerle kesikli kurutma oranlarını toplu olarak görmekte fayda olacağı için Şekil 19'da her güne ait MR'lerin toplu olarak çizimi görünmektedir.

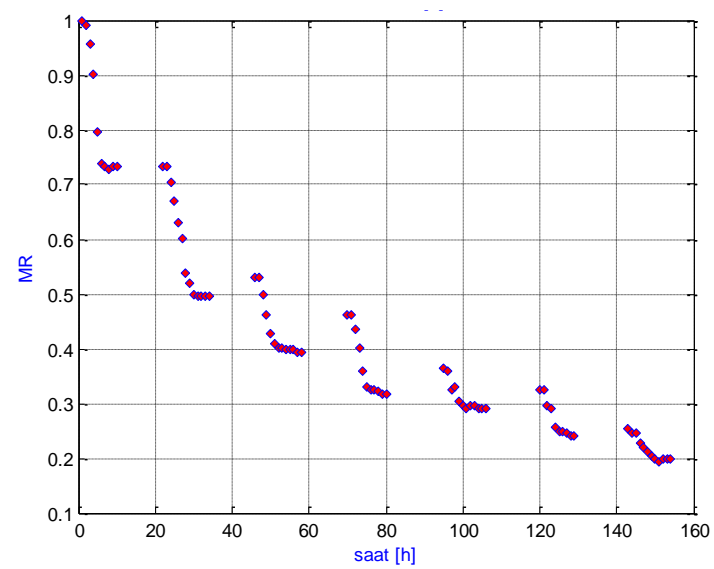

Şekil 19. Yedi günlük kurutma periyotlarının MR değerleri

Şekil 19'dan da anlaşılacağı üzere kurutma yapılan her günün sonunda kurutma hızı güneş radyasyonuna bağlı olarak anlamlı olarak azalmakta ve neredeyse hiç kurutma olmamaktadır. Eğer daha hassas bir ölçüm yapılabilseydi, az miktar radyasyonun ve hava akımının sayesinde biraz daha kurutmanın olduğu görülecektir. Her güne ait kurutma periyodunun ardından yapılan ölçümlerde, yarı kurutulmuş materyalin kütlesinde farklı oranlarda artış gözlemlenmiştir. Bunun sebebi yarı kurutulmuş mamullerin, denge nem içeriğine gelene kadar nem alabilmeleridir. Bunu önlemek için kurutma proseslerinde kurutma kabini ile dış ortam hava izolasyonunun iyi olarak yapılması gerektiği anlaşılmaktadır.

\section{SONUÇ VE ÖNERILER}

Gerek su içeriği ve gerekse su aktivasyonu bakımından çok yüksek değerlere sahip erik meyvesinin kurutulması için hasat işleminin yapıldığı ilk günler olan ağustos ayında kurutma yapılmasının daha iyi olacağı bu çalışmadan anlaşılmıştır. Aynı sistemin diğer meyve ve sebzelerde bazı değişiklikler ile yapılması 
durumunda daha iyi sonuçlar elde edilebileceği bu çalışmadan anlaşılmaktadır.

Kurutma işlemi için en uygun çevresel koşullar daha kuru ortam ile daha yüksek rakımlı yerde kurutma yapılması kurutma sistemi performansını daha da artıracaktır. Bilindiği gibi nispeten bağıl nemi daha düşük olan yüksek rakımlı yerlerde bu kurutma işleminin yapılması durumunda sistem verimliliğinin anlamlı bir şekilde artacağı hesaplanan değerlerden anlaşılmaktadır. Bunun nedeni yüksek rakımlı yerlerde kurutma havasının nispi nemi daha düşük olmakla birlikte yatay yüzeye gelen güneş radyasyonunun daha fazla olmasıdır. Kurutma işlemlerinin özellikle nemin yüksek olduğu yaz aylarında, bağıl nemin nispeten daha düşük olduğu yüksek rakımlı yerlerde yapılmasının daha iyi sonuçlar vermesinden dolayı yüksek rakımlı, düşük nemli ve yüksek radyasyonlu yerler önerilmektedir.

Diğer yandan yapılan bu çalışmanın önemli özelliklerinden olan konveyör taşıyıcı bandın otomasyonu ile daha hijyenik koşullarda yükleme ve boşaltma yapılma imkânı sunulmaktadır. Ayrıca bant ilerleme hızının kontrolü sayesinde daha endüstriyel ölçekli harici enerji destekli hibrit kurutma sistemleri için daha iyi sonuç vereceği bilinen bir gerçektir. Önerdiğimiz gibi modüler bir sistemin tam otomasyonun yapılması durumunda profesyonel olmayan işgücü ile kurutma işleminin yapılması da mümkün olmaktadır.

Erik gibi yüksek nem içeriği olan ürünlerin daha kısa sürede ve orta sıcaklıkta kurutulması çeşitli çalışmalarda önerilmektedir. Bunun nedeni uzun süreli ve yüksek sicaklıklarda kurutma işlemlerinde erik meyvesinin gıda içerikleri olumsuz yönde etkilenmesidir. Ayrıca sabit sıcaklıkta kurutma işlemlerinin daha iyi sonuçlar verdiği bilinmektedir. Bundan dolayı güneşlenmenin yeterli olmadığı saatlerde ve güneşin olamadığı saatlerde de kurutma imkânı sunan enerji depolayabilen materyaller ile güneş enerjisi gündüz gün 1şığında depolanabilmekte ve güneşlenmenin olmadığı saatlerde bu enerji kullanılabilmektedir. Sicaklığın değişkenliğini önlemek için doğalgaz destekli kurutma sistemi veya harici başka enerji kaynaklarının kullanılması durumunda stabil bir kurutma sıcaklığının elde edilmesi ile daha iyi sonuçlar alınacağ ${ }_{1}$ için hibrit kurutma sistemi önerilmektedir.

Son olarak kurutma işleminin direk güneş enerjisi ile yapılması yerine, sıcak hava sağlayıcı havalı güneş kolektörü gibi havanın kabine girmeden 1sitılması bu çalışmada önerilmektedir. Bunun nedeni ise; kurutma işlemini direkt güneş enerjisine maruz bırakırsak, hava sıcaklığını kontrol edemediğimiz için, önerilen sıcaklıkların üzerine çıkıldığında kurutulan materyalde olumsuz sonuçlar alınabilmektedir. Otomasyona uygun hava giriş sıcaklığı kontrolü için aktif dolaylı hibrit sistemlerin kullanılması bu çalışmada şiddetle önerilmektedir.

\section{KAYNAKLAR}

1. Rahaman, A., Siddeeg, A., Manzoor, M.F., Zeng, X.A., Ali, S., Baloch, Z., Li, J., Wen, Q.H., 2019. Impact of Pulsed Electric Field Treatment on Drying Kinetics, Mass Transfer, Colour Parameters and Microstructure of Plum, Journal of Food Sci Technol, 56(5), 2670-78.

2. Bayhan, H.A., 2004. Kabin Tipi Bir Kurutucuda Kurutma Sürecini Etkileyen Parametrelerin Deneysel Olarak İncelenmesi, Yüksek Lisans Tezi, Süleyman Demirel Üniversitesi Fen Bilimleri Enstitüsü, Isparta, 116.

3. Alonge, A.F., Hammed, R.O., 2007. A Direct Passive Solar Dryer for Tropical Crops, African Crop Science Conference Proceedings, El-Minia, Egypt, 27-31 October, 8, 1643-1646.

4. Akdeniz, B., 2011. Geleneksel Usullerde Sultani Çekirdeksiz Üzüm çeşidinin Kurutulması, Gida Teknolojileri Elektronik Dergisi, 6(1), 13-22.

5. Yıldız, Z., Gökayaz, L., 2019. Güneş Enerjili Kurutucuda Kurutulan Elma Dilimlerinin Kurutma Koşullarının RSM ile Optimizasyonu, Çukurova J. Agric. Food Sci., 34(2), 100-108.

6. Gürel, A.E., Ceylan, İ., Aktaş, M., 2016. Meyve ve Sebzelerin Kurutma Parametrelerinin İncelenmesi, Gazi Üniversitesi Fen Bilimleri Dergisi, Part: C, 4(4), 267-273. 
7. Güngör, A., 2013. Sebze ve Meyve Kurutmada Kullanılan Kurutucular ve Kurutma Teknolojileri, 11. Ulusal Tesisat Mühendisliği Kongresi, İzmir, 17-20 Nisan, 43-63.

8. Kobastar Elektronik, Load cell, https://kobastar.com/wp-

content/uploads/2017/10/sp8tr.pdf, Erişim Tarihi: 02.03.2021.

9. EMKO Elektronik, Thermocouples-(TC) Standart Bayonet Type "J" and "K" Type Thermocouples,

https://www.emkoelektronik.com.tr/en/product s/tc-standart-bayonet-type, Erişim Tarihi: 02.03.2021.

10. EMKO Elektronik, Humidity Sensors Pronem Midi (Wall type) https://www.emkoelektronik.com.tr/en/product s/pronem-midi-wall-type, Erişim Tarihi: 02.03.2021.

11. Dixell Asia Service Center, Humidity Probes, https://www.dixellasia.com/Dixell-HumidityProbes, Erişim Tarihi: 05.03.2021.

12. Delta AC Drives, Delta DOP-B10S615 DOP-B Series HMI Touchscreen, https://deltaacdrives.com/delta-dop-b10s615human-machine-interface/, Erișim Tarihi: 02.03.2021.

13. Delta AC Drives, DVP-SV2 Series PLC, https://deltaacdrives.com/delta-dvp-sv2-series/, Erișim Tarihi: 02.03.2021.

14. Delta Electronics, DVP04AD-S2 PLC Analog Modül,

https://www.deltaww.com/services/Download Center 2 . aspx $?$ secID $=8 \&$ pid $=3 \&$ tid $=0 \& C I D=0$ $6 \&$ typeID=3\&dataType $=\&$ key $=$ DVP04ADS2\&hl=en-US), Erişim Tarihi: 02.03.2021.

15. Kobastar Elektronik, Kontrol Tartım İndikatörleri-B60 Tartım Kontrolörü, https://kobastar.com/tr/productdetails/b60vinc-asiri-yuk-indikatoru/, Erişim Tarihi: 02.03.2021.

16. Delta Electronics, Industrial Automation Temperature Controllers, http://www.deltaemea.com/Products/CategoryListT1.aspx?CID $=060405 \& \mathrm{PID}=1297 \& \mathrm{hl}=\mathrm{en}$ -

GB\&Name $=$ DTC $\% 20$ Series, Erişim Tarihi: 23.12.2020. 